University of Miami Law School University of Miami School of Law Institutional Repository

1990

\title{
Brazil's New Constitution: An Exercise in Transient Constitutionalism for a Transitional Society
}

Keith S. Rosenn

University of Miami School of Law, krosenn@law.miami.edu

Follow this and additional works at: https://repository.law.miami.edu/fac_articles

Part of the Comparative and Foreign Law Commons

\section{Recommended Citation}

Keith S. Rosenn, Brazil's New Constitution: An Exercise in Transient Constitutionalism for a Transitional Society, 38 Am. J. Comp. L. 773 (1990).

This Article is brought to you for free and open access by the Faculty and Deans at University of Miami School of Law Institutional Repository. It has been accepted for inclusion in Articles by an authorized administrator of University of Miami School of Law Institutional Repository. For more information, please contact library@law.miami.edu. 


\section{KEITH S. ROSENN}

\section{Brazil's New Constitution: An Exercise in Transient Constitutionalism for a Transitional Society}

\section{INTRODUCTION}

After more than two decades of authoritarian military rule, Brazil has finally completed its incredibly slow transition from dictatorship to democratic government. ${ }^{1}$ On November 15, 1989 the entire Brazilian electorate, ${ }^{2}$ in contradistinction to one restricted to generals or legislators, had its first opportunity in 29 years to vote directly for a presidential candidate. Because none of the 21 candidates received a majority, a runoff election was held on December 17, 1989; it resulted in the election of Fernando Collor de Mello, a populist 40-year old former governor of the small northern state of Alagoas. The election was held pursuant to Brazil's new Constitution, which provided the critical framework for restoration of full democracy. In this respect, the Constitution worked well. Although the elections were hotly contested, no one seriously contests the legitimacy of Collor's presidential mandate.

The new Constitution is Brazil's seventh or eighth constitution, depending upon whether one counts a constitutional amendment that redrafted the entire constitution as a new constitution or as an

KEITH S. RosenN is Professor of Law, University of Miami.

1. The process began in $\mathbf{1 9 7 4}$ with the gradual liberalization of military regimes. Tancredo Neves, who was elected indirectly by the electoral college in January 1985, would have been the first civilian president in 21 years had he not died shortly before assuming office. On March 15, 1989, the Vice President, José Sarney, was sworn in as Brazil's transitional president. The length of the mandate of Brazil's "accidental president" was the subject of a bitter and costly dispute in the Constituent Assembly, which ultimately decided that Sarney's mandate would not terminate until March 15, 1990. The story of this transition is recounted in Mainwaring, "The Transition to Democracy in Brazil," in Brazil's Economic and Political Future 168 (Julian Chacel, Pamela Falk \& David Fleischer eds. 1988).

2. The electorate was expanded to include for the first time persons between the ages of 16 and 18 . Const. of 1988 , art. $14 \S 1^{\circ}$ II (c). Illiterates, a group that included more than 30 percent of the population at the last census, were enfranchised by Constitutional Amendment No. 25 of May 15, 1985. Military conscripts, however, remain disenfranchised during the period of their obligatory military service. Const. of 1988, art. $14 \S 2^{\circ}$. Voting is optional for those between the ages of 16 and 18 , those over 70, and illiterates; it is obligatory for all others. Id., art. $14 \S 1^{\circ}$.

During the last popular presidential election, held in 1960, fewer than 12 million persons voted. During the runoff presidential election in December 1989, 55,492,560 votes were cast, equivalent to 67.61 percent of the total electorate. Gazeta Mercantil, Dec. 19,1989 at 1 . 
amendment. ${ }^{3}$ It replaces the 1969 Constitution, promulgated by the three ministers of the Armed Forces pursuant to authority the military conferred upon itself by a series of Institutional Acts, and whose legitimacy was decidedly dubious. ${ }^{4}$ The 1969 Constitution, like its 1967 predecessor, was designed to institutionalize a de facto military regime and to insure its survival. One of its basic features was centralization of power. It transferred a considerable amount of power from the states and municipalities to the federal government, leaving Brazilian federalism a shadow of its former self. Although formally providing for a tripartite division of power among the executive, legislative, and judicial branches, a substantial amount of legislative power was transferred to the Executive. Moreover, both the Legislature and Judiciary were purged of elements whom the military deemed insufficiently sympathetic to the goals of the 1964 Revolution. ${ }^{\mathbf{5}}$

The period preceding promulgation of the 1969 Constitution was one of constant crisis resulting from widespread opposition to the military government. The government responded by issuing a series of 12 Institutional Acts that continuously modified the 1967 Constitution in accordance with the military command's assessment of the needs of the moment. A constitution that can be modified by the government's unilateral declaration that it has decided to utilize a self-proclaimed ambulatory constituent power is, like the Emperor's new clothes, only a transparent disguise for naked power. In 1972,

3. Brazil's prior constitutions are: (1) the Constitution of 1824 , which established a constitutional monarchy; (2) the Constitution of 1891 , which established a republican government; (3) the Constitution of 1934, which institutionalized the Second Republic following the 1930 Revolution; (4) the Constitution of 1937, which institutionalized the dictatorship of Getúlio Vargas; (5) the Constitution of 1946, which restored democracy after the ouster of Vargas; (6) the Constitution of 1967, which institutionalized the military regime that came to power in 1964; and (7) the Constitution of 1969 , issued technically as Amendment $\mathrm{N}^{\circ} 1$ to the 1967 Constitution, but which revised and renumbered the entire text as a matter of form, while making relatively few important substantive changes. Some authors regard this a new constitution; others treat it as merely an amendment of the 1967 Constitution. See Orlando Soares, Comentários à Constituição da República Federativa do Brasil 84-86 (3d ed. 1990). Here the 1969 Amendment is treated as a new constitution. The constitutional texts, along with an index, are collected in the two-volume compilation of the Senado Federal, Constituiçóes do Brasil (1986). For brief descriptions of Brazil's constitutions, see Alves, "Constituições do Brasil," Rev. Dir. Const. e Ciencia Pol. 1 (Número Especial 1987); Coelho, "Brasil de Muitas Constituições," in O Processo Constituinte 1987-1988, 23 (Milton Guran ed. 1988).

4. An institutional act is an expression of the constituent power exercised by a successful revolution. The theoretical explanation for the legitimacy of this exercise of power is contained in the Preambles to the First and Second Institutional Acts, translated in Kenneth Karst \& Keith Rosenn, Law and Development in Latin American 205-208 (1975).

5. See Karst \& Rosenn, supra n. 4 at 214-215; Skidmore, "Politics and Economic Policy Making in Authoritarian Brazil, 1937-71," in Authoritarian Brazil: Origins, Policies, and Future 3, 6-11, 38-41 (Alfred Stepan ed. 1973). 
Professor Riordan Roett concluded, with considerable justification, that the military's commitment to constitutionalism was basically cosmetic. ${ }^{6}$

\section{The Convoluted Process of Drafting the New Constitution}

The notion that the military lacked any serious commitment to constitutionalism became gradually less tenable during the 1974-1985 phase of political liberalization known as distensão (liberalization), when the most authoritarian features of the military regimes were eventually relaxed by subsequent constitutional amendments. ${ }^{7}$ Nonetheless, most Brazilians felt that a democratic Brazil ought to be governed by a new constitution. During his campaign, Presidentelect Neves promised a new constitution, and Sarney, his Vice-President and successor, resolved to fulfill that promise. Unfortunately, the birth of the new constitution was poorly conceived. Instead of convoking a separate constituent assembly, President Sarney proposed a constitutional amendment, which Congress adopted, empowering the next Congress to serve as a constituent assembly. ${ }^{8}$

The decision to have the new Congress double as a constituent assembly was an unfortunate mistake for several reasons. First, it was politically unfair because the next Congress included 23 senators elected in 1982 under the prior authoritarian regime's electoral legislation, which under-represented the more liberal parts of the country. These senators had no specific mandate to serve as part of a constituent assembly. ${ }^{9}$ Moreover, the Congressional election was held just before the electorate realized how badly it had been deceived by Sarney's Cruzado Plan, a wage increase/price freeze that created the illusion of monetary stability and relative prosperity, but did nothing to eliminate the underlying causes of the soaring

6. Professor Roett wrote:

"It seems clear that the military feel the need to preserve the myth of constitutionalism that has marked Brazilian history in both the 19th and 20th centuries. It is also clear that the military regime feels little compunction in violating both the spirit and the letter of the constitution when it is deemed necessary in the interests of the Revolution. Thus, the Institutional Acts represent the reality of the 1964 movement in that they are authoritative statements of the regime's political purpose; the constitution remains a legal exercise that is retained because it signifies so little in reality. It is a juridical statement of intent, not a political statement of relevance to the governance of the Brazilian state." Roett, "A Praetorian Army in Politics: The Changing Role of the Brazilian Military," in Brazil in the Sixties 3, 27 (Riordan Roett ed. 1972).

7. For a concise description of the evolution of the 1969 Constitution up to 1985 , see Manoel Gonçalves Ferreira Filho, Comentários à Constituição Brasileira 28-38 (6th ed. 1986).

8. Constitutional Amendment No. 26 of November 27, 1985.

9. At its second session, the Constituent Assembly decided to permit these 23 senators to vote in the Constituent Assembly. 
inflation it had temporarily suppressed. ${ }^{10}$ Had the election been held after the badly disillusioned electorate realized that the Cruzado Plan was a fiasco, and that the country was in the grip of the worst inflationary crisis in Brazilian history, it is doubtful that the government's party, the PMDB, would have been able to elect a majority of the seats in the new Congress. ${ }^{11}$ Second, from a functional standpoint, combining normal legislative powers and constitutionmaking powers in the same body made no sense, for the two functions interfered with each other. Congress is a highly political body with a short-term perspective and agenda. Constitutions should be elaborated by statesmen with a long-term and nonpartisan perspective. As a basic political player, Congress had a clear conflict of interests. It is not surprising that the constitutional document it drafted aggrandized Congressional power at the expense of other institutions and conferred numerous favors upon special interest groups.

If there were any truth to the old canard that a camel is a horse drafted by a committee, the new Brazilian Constitution would resemble a hydra-headed Pegasus. On September 3, 1985, President Sarney appointed a group of fifty "notables," called the Afonso Arinos Commission, to prepare the first draft of the Constitution. The Arinos Commission's draft, however, was far too liberal for the conservative Sarney, who refused to submit it to Congress for consideration. ${ }^{12}$ The Constituent Assembly then considered the question of whether to commission a draft constitution and firmly rejected the idea as a "dangerous instrument of control over the Assembly."13 The basic drafting was undertaken from scratch by the entire 559member Congress, which divided itself into eight committees, each made up of 63 regular members and a similar number of auxiliary members. Committee assignments were designed to reflect the proportional weight of each political party's membership in the Congress. Each committee, in turn, was divided into three

10. The history of the ill-fated Cruzado Plan is recounted in Faria, "Macroeconomic Policymaking in a Crisis Environment: Brazil's Cruzado Plan and Beyond," in Brazil's Economic and Political Future 42 (Julian Chacel, Pamela Falk \& David Fleischer eds. 1988).

11. In large part because of strategic concealment of the disastrous results of the Cruzado Plan until after the election, the PMDB managed to elect 298 out of the 559 members of Congress. For a detailed study of the social, economic, educational, and political background of the members of the Congress, see Fleischer, "Perfil SócioEconômico e Político da Constituinte," in O Processo Constituinte 1987-1988, 29 (Milton Guran ed. 1988).

12. The draft constitution prepared by the Commission is published in Constituição Federal; Anteprojeto da Comissão Afonso Arinos; Índice Analitico Comparativo 115-272 (Ivan Torres Júnior ed. 1987). For a critical commentary on the work of the Arinos Commission, see Ney Prado, Os Notáveis Erros dos Notáveis (1987).

13. Lucas Coelho, "O Processo Constituinte," in O Processo Constituinte 1987. 1988, 41, 43 (Milton Guran ed. 1988). 
subcommittees. The Herculean task of integrating and harmonizing the oft-times conflicting work product of these 24 drafting groups was the task of the Committee on Systematization, made up of 93 members of Congress.

This unwieldy drafting process was made even more cumbersome by an unprecedented amount of popular participation. The Assembly's Internal Regulations required each subcommittee to devote five to eight sessions to hearing from entities representing different sectors of Brazilian society. Those heard included such diverse groups as government ministers, unions, landlords, Indians, street urchins, prostitutes, homosexuals, and maids. The Assembly established a computerized data bank containing the thousands of popular suggestions concerning the contents of the new constitution. During the seemingly interminable deliberations, virtually all aspects of Brazilian society were debated. In principle, nothing was deemed too trivial for possible inclusion in the new constitutional text. Some 61,142 amendments were proposed; some 21,000 speeches were delivered. The annals of the Constituent Assembly filled 100 volumes. ${ }^{14}$ Each article of the text of the quasi-final draft had to be approved twice by a majority of the entire Congress. This proved to be fortunate, for a number of the more bizarre provisions, such as the one that protected the right to life, even during cases of fatal illness, were eliminated in this process.

After an abortive last ditch effort by President Sarney to sabotage the entire process and a final edit for style, the Constitution was finally promulgated on October 5,1988 , nineteen months after its gestation period began. No plebiscite or other ratification procedure was held.

\section{AN Overview of THE New Constitution}

Brazil's long awaited Constitution is a lengthy, detailed and convoluted document, containing 245 articles and 70 transitory provisions. ${ }^{15}$ Together these 315 articles take up 193 pages in the official publication. The drafters obviously ignored the wisdom in John Marshall's celebrated dictum in McCulloch $v$. Maryland:

A constitution, to contain an accurate detail of all the subdivisions of which its great powers will admit, and of all the means by which they may be carried into execution, would partake of the prolixity of a legal code, and could scarcely

14. Lombardo, "A Constituição: Resultado de 613 dias de trabalho," Gazeta Mercantil, Oct. 6, 1988 at 1; Jornal do Brasil, Sept. 3, 1988, 1st Caderno at 4.

15. The Constitution went through nine different drafts. Earlier drafts were even more voluminous and convoluted. The first draft, nicknamed "Frankenstein," contained 501 articles. 
be embraced by the human mind. It would probably never be understood by the public. Its nature, therefore, requires, that only its great outlines should be marked, its important objects designated, and the minor ingredients which compose those objects be deduced from the nature of the objects themselves. ${ }^{16}$

Instead, they included in the constitutional text a great many detailed rules normally found in ordinary legislation or regulations.

This confusion of constitutional rules with ordinary legislation resulted from five factors. One was the role confusion created by having the Congress double as a Constituent Assembly. The second was the generalized concern about disrespect for law; many felt enshrinement of detailed rules in the Constitution, rather than ordinary legislation, was the only way to insure that they would be respected. The third was the widespread belief that a constitution can be a societal panacea and that Brazil's gargantuan economic and social problems could be miraculously cured by the choice of appropriate words in the constitutional text. ${ }^{17}$ The fourth was Brazil's prolix constitutional tradition; Brazil has never had a concise constitution. ${ }^{18}$ Finally, there was the influence of the dirigiste model of the 1976 Portuguese Constitution, a lengthy, programmatic document designed to determine the political course of action of future governments.

\section{A Constitution only partly in force}

Paradoxically, despite the great detail with which many areas have been regulated, a vast amount of implementing legislation must be enacted in order to make Brazil's new Constitution fully effective. According to Saulo Ramos, Minister of Justice in the Sarney regime, the Constitution requires enactment of some 285 ordinary statutes and 41 complementary laws in order to effectuate its provisions. ${ }^{19}$ This is the result of the programmatic and polemical nature of many of its provisions; ${ }^{20}$ only by postponing the details to future legislation was the Constituent Assembly able to complete the Con-

16. 4 Wheat. 316,407 (1819).

17. The naive faith that almost any social or economic ill can be cured by legal prescription is part of the legal legacy that Brazil inherited from Portugal. Rosenn, "Brazil's Legal Culture: The Jeito Revisited," 1 Fla. Int l L. J. 1, 19 (1984).

18. Costa \& Amaral, "Necessidade de uma Constituição concisa," 298 Rev. For. 107, 109-110 (1987).

19. Ramos, "A honra substabelecida," Folha de São Paulo, Sept. 16, 1990.

20. The Constitution's programmatic nature is apparent throughout. Thus, Article 3 states that country's fundamental objectives are:

I- to construct a free, just and unified society;

II- to guarantee national development;

III- to eradicate poverty and marginal living conditions and to reduce social and regional inequalities; 
stitution. Thus far, Congress has failed to comply with most of the directives and deadlines it formulated when wearing its Constituent Assembly hat. The great bulk of the implementing legislation has yet to be enacted, ${ }^{21}$ leaving many provisions inoperative and producing considerable litigation by persons or groups seeking to implement constitutional guarantees without having to wait for the implementing legislation. ${ }^{22}$ In addition, thousands of existing laws have been implicitly revoked or need to be modified to conform with the new Constitution; failure to adapt existing legislation to new constitutional requirements has left many areas in a state of juridical chaos. ${ }^{23}$

\section{Basic flaws in design and drafting}

Like a cathedral originally constructed as a hotel, the new Constitution is structurally flawed. Initially, a majority of the Constituent Assembly appeared to be committed to choosing a parliamentary system of government, and many provisions were framed in contemplation of a parliamentary form of government. Even though a presidential system was ultimately adopted, a number of parliamentary provisions have remained in the text. As Ulysses Guimarães, who presided over the Constituent Assembly, put it: "The body is parliamentary, with presidential attire." 24 As will be seen, institutions like the provisional measure, which were designed for a parliamentary system, have become seriously distorted in a presidential system. ${ }^{25}$

The new Constitution lacks organic unity. Because it was drafted without any master plan by 24 Congressional subcommittees, the Constitution contains no coherent vision as a plan of government. It is a hodgepodge of progressive, conservative, liberal,

IV- to promote the well-being of all, without prejudice as to origin, race, sex, color, age and any other forms of discrimination.

21. One year after the Constitution's promulgation, only 30 implementing measures had been enacted. These are set out in Garcez, "Os dispositivos da Constituição já regulamentados," Gazeta Mercantil, Oct. 6, 1989 at 35. At the end of July 1990, nearly 300 constitutional provisions were still awaiting implementing legislation. Sigrist, "A importância da autoridade do Congresso para a democracia," Gazeta Mercantil, July 21 \& 23,1990 at 5.

22. Examples of constitutional provisions that have generated considerable unsuccessful litigation to enforce them in the absence of implementing legislation are the prohibition against charging more than 12 percent annual interest in real terms, the guaranty against arbitrary discharge of employees, and the right of civil servants to strike. See Trevisan, "A Constituição que ainda não está em vigor," Gazeta Mercantil, Mar. 1, 1990.

23. Ramos, supra n. 19.

24. Guimarães, "Constituição—certos erros e principios fundamentais," Folha de São Paulo, May 6, 1990 at A-3.

25. See nn. 47-54 infra and the accompanying text. 
radical, and moderate provisions, all rather uncomfortably ensconced side-by-side in the same document.

Brazil's 1988 Constitution is also poorly drafted. Some articles are absurdly long, such as Article 5, which contains 77 subdivisions and 22 subsections. Some provisions are unclear, overlapping, or redundant. Provisions that ought to be grouped together are sometimes scattered throughout disparate parts of the document. Illustrative of the style of the new Constitution is the way in which it protects freedom of speech and the press.

\section{Freedom of speech and press}

The new Constitution contains several free speech and free press provisions that commendably broaden prior constitutional guarantees by eliminating prior restraints. ${ }^{26}$ Whereas prior free speech and press guarantees were rather concisely stated in a single article, ${ }^{27}$ they are now widely dispersed in a series of sometimes overlapping or redundant provisions. The first is Article 5, subparagraph IV, which cryptically states:

Manifestation of thought is free, but anonymity is forbidden.

Article 5, subparagraph IX, then overlaps and somewhat confusingly expands this guarantee by providing:

Expression and communication of intellectual, artistic, and scientific activity are free, independent of any censorship or

license.

Just in case one missed the message, more than one hundred articles later, these guarantees are reiterated in Article 220:

26. The issue of whether the Constitution should ban prior censorship is an old one in Brazil. The Constitutions of 1824 and 1891 generically prohibited censorship, but many, including the members of the nation's highest court, did not interpret this prohibition to prevent prior censorship of public shows and diversions. Since 1934, all Brazilian Constitutions, except for the present one, have permitted censorship of public shows and diversions. Gonçalves Ferreira Filho, supra n. 7 at 591.

27. Article $153 \S 8$ of the 1969 Constitution provided:

"Manifestation of thought, political or philosophical conviction, is free, as well as the rendering of information independent of censorship, except in public diversions and shows, each one being liable, in the terms of the law, for the abuses he commits. The right of reply is assured. The publication of books, newspapers, and magazines does not depend upon the license of an authority. But propaganda of war, subversion of order or religious, racial or class bias, and publications and dramatizations contrary to morality and good customs will not be tolerated."

Despite this seemingly significant guarantee of free speech and press, the military regimes imposed blatant censorship on the press and the public in the name of national security. See Dassin, "Press Censorship and the Military State in Brazil," in Press Control around the World 149-186 (Jane Curry \& Joan Dassin eds. 1982). Cf. Dassin, "The Brazilian Press and Politics of Abertura," $26 \mathrm{~J}$. Inter-Am. Stud. \& World Aff. 385 (Aug. 1984). 
The expression of thoughts, creation, speech and information, through whatever form, process or vehicle, shall be subject to no restrictions, observing the provisions of this Constitution.

$\S 1^{\circ}$. No law shall contain any provision that might constitute an impediment to the full freedom of information by the press in any medium of social communication, observing the provisions of art. 5, IV, V, X, XIII, and XIV.

$\S 2^{\circ}$. Any and all censorship of a political, ideological and artistic nature is prohibited. ${ }^{28}$

The new Constitution creates a vague, undefined constitutional right to information, as well as a constitutional shield that may enable journalists to protect their sources. It assures everyone "access to information, safeguarding the secrecy of sources whenever necessary for the exercise of one's profession."29 Article 5, subparagraph XII, safeguards the secrecy of correspondence, data, and telegraphic and telephonic communications, permitting wiretaps only by judicial order in connection with criminal investigations or prosecutions.

All of these guarantees are qualified, and to a certain extent undermined, by provisions designed to safeguard actions for libel, slander, and the protection of privacy. Thus, Article 5, subparagraph V, safeguards "a right of reply, proportional to the injury," as well as a right to compensation for material and moral damages. ${ }^{30}$ It also safeguards a right to indemnification for damages to one's image, although what that adds to material and moral damages is unclear. Article 5, subparagraph $X$, rather redundantly provides that:

Personal intimacy, private life, honor, and reputation are inviolable, guaranteeing the right to compensation for pecu-

28. The remainder of Article 220 permits the federal government to inform the public about the nature of shows and exhibitions and to establish measures allowing the public to defend itself against unwanted radio and TV programs. It also permits governmental regulation of advertisements for tobacco, alcohol, agro-toxics, and medicines.

29. Const. of 1988, art. 5, subpara. (XIV). The right of access to certain kinds of government information is also secured by Article 5, subparagraph LXXII, which creates a constitutional procedural innovation, habeas data, discussed infra at $\mathrm{nn}$. 107-110 and accompanying text. In 1977, a right of information was added to Article 6 of the Mexican Constitution, but legislation clarifying and implementing this right has yet to be enacted. A statutory right to freedom of information has been created in a number of countries, including Sweden, France, Norway, Canada, and the United States. See Quintanilla-Madero, "Toward a Law of Public Access to Government Information in Mexico," 20 U. Miami Inter-Am. L. Rev. 93, 99 (1988).

30. Like other civil law jurisdictions, Brazil distinguishes between material damages, which result in a diminution of the victim's patrimony through pecuniary loss and physical injury, and moral damages, such as pain, suffering, or emotional distress, which do not reduce the victim's patrimony. See generally, Wilson Melo da Silva, O Dano Moral e Sua Reparação (3d ed. 1983); Litvinoff, "Moral Damages," 38 La. L. Rev. 1 (1977); Friedler, "Moral Damages in Mexican Law," 8 Loy. L.A. Int'l \& Comp. L. J. 235 (1986). 


\section{niary and moral damages resulting from the violation thereof.}

The Brazilian Penal and Civil Codes impose potentially serious liability for calumny, defamation, and injury, which are considered both torts and crimes. ${ }^{31}$ Brazil also has a Press Law that imposes criminal liability upon journalists. ${ }^{32}$ Given the potential criminal and civil liabilities that can be imposed under Brazilian law for defamation or calumny, particularly with respect to criticisms of officials, it is difficult to square the constitutional guarantees of freedom of speech and freedom of the press with the constitutional guarantees of damages for injuries to honor and reputation. ${ }^{33}$

31. Libel, slander, and invasion of privacy are both criminal offenses as well as torts in Brazil. Article 138 of the Brazilian Penal Code makes calumny (calrinia)falsely accusing someone of activity or an omission that constitutes a crime-punishable by six months to two years in detention. Article 139 of the Penal Code makes defamation (difamaçä)-attributing to someone a fact offensive to his or her reputation-punishable by three months to a year in detention. Article 140 of the Penal Code makes indignity (injiria)-injuring someone by offending his sense of dignity or decency-punishable by one to six months in detention.

These offenses are also punishable by fines of up to 1800 times the monthly minimum wage, roughly $\$ 99,000$ to $\$ 140,000$ in the past year, depending upon the exchange rate and changes in the minimum wage rate. Penalties and fines are increased by one-third if the victim is the President of Brazil, head of any foreign government, or a public functionary. They also increase by one-third if the offense is committed in the presence of several people or in a way that the information is likely to be widely divulged. The penalties double if the offense is committed for money.

One may also be held civilly liable for committing any of these offenses. Legally, damages may be up to twice the maximum fine. Civil Code, art. 1547.

Truth is an affirmative defense only in a calumny action. It can be used as a defense in a defamation action only if the aggrieved party is a public employee and the offense referred to his exercise of official functions. Truth is no defense to an action for indignity.

32. Article 20 of Law No. 5.250 of Feb. 9, 1967 (the Press Law) makes it a crime punishable by detention from six months to three years and a fine of up to 20 times the minimum wage to publish through the media a false accusation of a criminal act or omission. If the offended victim is the President of the Republic, the President of the Senate or the Chamber of Deputies, a Minister of the Supreme Federal Tribunal, the head of a foreign government, or a foreign diplomat, truth cannot be proven as a defense. Art. $20 \S 3$. Article 21 makes it a crime, punishable by detention from three to 18 months and a fine of up to ten times the minimum wage, to defame someone through the media by attributing a fact offensive to his reputation. Article 22 makes it a crime, punishable by detention of one month to one year or a fine up to ten times the minimum wage, to injure someone through the media by offending his sense of dignity or decency.

33. See Ramos, supra n. 19. In practice, however, these potential liabilities are not a serious constraint upon freedom of speech and the press, largely because of the historic tendency of Brazilian courts to award low damages and because proceedings normally drag on for many years. Vigorous political debate goes on despite threats of defamation actions, and the Brazilian media continually report on corruption and scandals in high places and openly criticize government policies and officials. Some charge that various newspaper and television firms engage in self-censorship for fear of government retaliation with respect to advertising and credit, but that charge is difficult to accept in view of what is actually printed and aired in Brazil, and is vigorously denied by many media sources. See U.S. Dept. of State, Country Reports on 


\section{Planned obsolescence}

The new Brazilian Constitution, like so much modern machinery, is an example of planned obsolescence. In sharp contrast with the U.S. Constitution, which was ". . . intended to endure for ages to come, and, consequently, to be adapted to the various crises of human affairs,"34 Brazil's new Constitution was intended to endure for only five years. On September 7, 1993, the Constitution calls for the holding of a plebiscite to determine whether Brazil should remain a republic or become a constitutional monarchy, and whether it should retain presidentialism or adopt parliamentarianism. ${ }^{35}$ The Constitution calls for revision of its text in October 1993, by a vote of an absolute majority of the members of the National Congress. ${ }^{36}$ This is an incredibly unwise and dangerous provision, for it makes the entire Constitution amendable by a single majority vote of both houses of Congress. ${ }^{37}$ It thus defeats one of the most basic purposes of a written constitution; namely the preservation of a particular vision of structuring and limiting power and protecting that vision from being easily overthrown by future generations. ${ }^{38}$ Ironically, the drafters of Brazil's Constitution deliberately designed a charter that is likely to self-destruct after only five years. Many, including President Collor, are so disenchanted with the Constitution that they are urging that the general constitutional revision now set for 1993 be moved up to 1991 or 1992.

\section{Basic Reallocations of Power}

The new Constitution was designed to weaken the Executive and strengthen the Legislature. The Constitution makes the President accountable to Congress, which can, at least in theory, sanction him or impeach him. ${ }^{39}$ The House or the Senate, or one of their Commissions, can require that any Minister of State appear person-

Human Rights Practices for 1989, Jt. Rep. to House Comm. on For. Affs. \& Sen. Comm. on For. Rel., 101st Cong., lst Sess. 489 (1990) [hereafter cited as Country Reports].

34. McCulloch v. Maryland, 4 Wheat. 316, 415 (1819).

35. Const. of 1988, Transitory Provisions, art. 2.

36. Id., Transitory Provisions, art. 3.

37. Constitutional amendments may be proposed by the President, one-third of the House of Representatives or the Senate, or more than one-half the state legislatures. Approval requires two successive votes by at least three-fifths of each house of Congress. The only provisions that may not be amended are the federal system of government; direct, secret, universal, and periodic suffrage; separation of powers; and the individual rights and guaranties. Const. of 1988, art. 60.

38. Levinson, "Law as Literature," 60 Tex. L. Rev. 373, 376 (1982).

39. Impeachment was provided for ministers of state under Brazil's 1824 Constitution. Art. $47 \S 2^{\circ}$. Provision for impeachment of the president has been part of Brazilian constitutions since 1891 . E.g, Const. of 1891 , arts. 53 and 54. Although there have been a number of well-qualified candidates, no Brazilian president has ever faced impeachment charges. 
ally before it and testify or answer written interrogatories. Failure to comply without good reason constitutes cause for impeachment. ${ }^{40}$ Congress has exclusive competence to accept or reject any international agreement that has serious financial consequences for the national patrimony, 41 a provision that is likely to complicate greatly Brazil's efforts to renegotiate its foreign debt and to conduct foreign policy. ${ }^{42}$

Potentially, the most important power transference was the attempt to concentrate virtually all law making powers in the Congress. This was a reaction to one of the most abused aspects of the constitutional system imposed by the military regimes, legislation by Executive decree. ${ }^{43}$ The new Constitution, therefore, deprives the President of the power to issue decree-laws.44 In addition, the Constitution seeks to give Congress exclusive power to control rulemaking by administrative agencies. Hence, all acts of the Executive, including acts of indirect administration, are theoretically made subject to either direct control of the Congress or through the control of the Chamber of Deputies or the Senate alone. ${ }^{45}$ Despite these measures, the real focus of decision-making power has remained in the Executive.

\section{The provisional measure}

In place of the decree-law, the new constitutional scheme authorizes the Executive to issue delegated laws with prior Congressional assent. Except for a few reserved subjects, Congress may delegate to the President the power to enact legislation. ${ }^{46}$ In cases of relevance and urgency, the President may also issue provisional measures, which have the force of law, but he must submit these measures immediately to Congress. If not converted by Congress into law within 30 days, provisional measures lose their efficacy $a b$ initio, a feature

40. Const. of 1988 , art. $50 \& 50 \S 2$.

41. Id., art. 49 , subpara. I.

42. For example, Senate Resol. No. 62 of Dec. 15, 1989, imposes a limit of 10 percent of net real receipts (about U.S. $\$ 10$ billion) on all foreign and domestic borrowing by the Federal Government and its agencies.

43. Under Article 55 of the 1969 Constitution, in cases of emergency or relevant public interest, the President had the power to issue decree-laws dealing with national security, public finance, and public employment. These decree-laws had the force of law as soon as published. Congress had 60 days to disapprove them, but could not amend them. Until specifically disapproved, decree-laws remained in force. Military presidents were not the only ones to resort to decree-laws; President Sarney issued 209 of these measures between 1985 and 1988.

44. Transitory Article 25 provided for revocation of decree-laws not ratified by Congress within 180 days after promulgation of the Constitution.

45. Const. of 1988 , art. 49 , subpara. $X$.

46. Const. of 1988, art. 68 . The form of delegation is a Congressional resolution setting forth the subject and the terms of the delegation. 
fraught with potential for creation of juridical chaos. ${ }^{47}$

The delegated law has seen little use, but the provisional measure, which was designed as an extraordinary device, has become a celebrated example of the Brazilian jeito, a highly prized paralegal institution for bending legal norms to expediency. ${ }^{48}$ The provisional measure has been regularly utilized by both Presidents Sarney and Collor to enact a wide variety of legislative initiatives. As of December 17, 1990, some 290 provisional measures have been promulgated, the great bulk of which have been approved by Congress. If not approved by Congress within thirty days, provisional measures have often been repromulgated. Indeed, provisional measures specifically disapproved by Congress have occasionally been repromulgated, generating serious debate about the constitutionality of the practice. The Supreme Federal Tribunal appears to have resolved the controversy by holding that it is unconstitutional for the President to republish a provisional measure that has been rejected by Congress. ${ }^{49}$ Recently, President Collor voluntarily withdrew three provisional measures whose constitutionality had been challenged in a direct action brought by the Procurator General before the Supreme Federal Tribunal. Collor accepted the Procurator General's position that a provisional measure rejected by Congress may not be repromulgated and that criminal penalties must be imposed by law rather than by provisional measures. ${ }^{50}$

The concept of the provisional measure was borrowed from Italy, which has a parliamentary form of government. Transplanted to Brazil, the provisional measure has become the critical device for retaining legislative initiative with the Executive. Failure to surround the provisional measure with sufficient safeguards to prevent executive domination of the legislative process has been a widely acknowledged major drafting deficiency of the constitution. ${ }^{51}$

47. Const. of 1988, arts. 62 and 84, subpara. XXVI. For an excellent analysis of the provisional measure, see Tácito, "As medidas provisórias na Constituição de 1988," 305 Rev. For. 13 (1989).

48. See Rosenn, "Brazil's Legal Culture: The Jeito Revisited," 1 Fla. Int $\eta$ L. J. 1 (1984). 6.

49. "STF mantém liminares suspensas," Gazeta Mercantil, June 23 \& 25, 1990 at

50. Castro, "Collor reconhece ilegalidade de três medidas provisórias," Gazeta Mercantil, Aug. 24, 1990. President Collor withdrew Provisional Measures 153 and 156 because they imposed criminal penalties; he withdrew Provisional Measure 190 because it was a repromulgation of Provisional Measure 185, which had been specifically rejected by Congress.

51. For example, Ulysses Guimarães recently admitted:

"We were also improvident in permitting provisional measures in art. 62 without the indispensable safeguards. We gave the President of the Republic irresponsible privileges. First, to legislate by decrees that have instantaneous effect as laws for up to 30 days. Second, we did not limit the area of this power, which can invade, and indeed is invading, the exclusive powers of the National Congress, Federal Senate or Chamber of Deputies. 
Thus, in practice the President has dominated the legislative process through his ability to issue provisional measures with the force of law.52 Although an occasional measure has been rejected by Congress, most have been approved or have not been acted upon within 30 days. Instead of initiating its own legislation, Congress has spent much of its time debating whether to approve provisional measures sent to it by the Executive.

Nor has the Judiciary proved to be much of a check upon the Executive's use and misuse of the provisional measure. The only constitutional limitation on the President's decision to issue a provisional measure is that the matter be relevant and urgent, but determination of relevance and urgency has been regarded as an issue solely for the President's determination, rather than a legal issue for the courts. When he sought to insulate certain constitutionally dubious measures from effective judicial review, President Collor simply issued a provisional measure depriving the courts of the power to issue preliminary injunctions against the economic measures contained in the Collor Plan. When Congress failed to ratify this provisional measure, Collor simply republished it four more times until Congress finally enacted it into law. ${ }^{53}$ Previously, the Supreme Federal Tribunal, Brazil's highest court, had refused to declare such a limitation on the remedial powers of the courts unconstitutional, preferring to let Congress bear responsibility for interfering with the government's economic recovery program. ${ }^{54}$

\section{Tax revenues}

The new Constitution redistributes a substantial amount of tax revenue from the federal government to the states and municipalities, but it does nothing to improve basic inequalities in the tax system. It has been calculated that the percentage of federal tax revenues that will be transferred to the states and municipalities will increase from the present 33 percent to 38.8 percent. Conse-

Third, because the President of the Republic can repeatedly issue provisional measures without limits, even when rejected by passage of time or by the Congress." Guimarāes, supra n. 24.

52. The Constitution also grants the President exclusive powers to initiate certain kinds of legislation, such as laws affecting the Armed Forces, financial matters, public employment, or administrative organization. Const. of 1988, art. $61 \S 1$.

53. The prohibition against preliminary injunctions challenging Collor's economic reforms was first issued as Provisional Measure No. 173 on March 18, 1990, which expired because it was not examined by Congress within thirty days from its publication. It was republished as Provisional Measure No. 182 on April 23, 1990. It was then republished as Provisional Measure No. 186 on May 23, 1990, Provisional Measure No. 192 on June 22, 1990, and Provisional Measure No. 198 on July 26, 1990. Finally, Congress approved Provisional Measure No. 198, making it Law No. 8,076 of August 23, 1990.

54. The vote was 7 to 2. Decision of Apr. 5, 1990, reported in Gazeta Mercantil, Apr. 6, 1990 at 31 . 
quently, federal tax receipts will diminish by about 17.6 percent, gradually becoming a diminution of about 21.6 percent by 1992.55 The immediate response of the Sarney government, however, was to launch a program called "Operação Desmonte," which more than nullified the redistributive effect of this reform by transferring to the state and local governments more of the burdens of funding certain social programs, such as education and health. The lament of the state and local governments has been that the burdens transferred to them more than offset the great share of federally collected revenues they will receive.

The Constitution contains programmatic provisions indicating how tax revenues are to be spent. For example, Article 212 provides that the Federal Government will spend at least 18 percent of its tax revenues, and the States, Federal District, and counties at least 21 percent of their tax revenues, on the maintenance and development of education. This provision has already resulted in a direct action of unconstitutionality filed before the Supreme Federal Tribunal by the Procurator General, challenging the 1990 Budget Law for noncompliance. This caused the Gazeta Mercantil, Brazil's Wall Street Journal, to editorialize:

In requesting the Supreme [Tribunal] to consider such a change in expenditures unconstitutional, the Procurator General called attention to the failings of a Congress that voted a constitution and soon thereafter regarded it, in this specific case, as a dead letter, in which it was accompanied, with apparent vacillation, by the renewed Executive. ${ }^{56}$

\section{Strengthening of the judiciary}

The powers of the judiciary have been strengthened. Article 99 guarantees the financial and administrative autonomy of the judiciary by allowing the courts to elaborate their own budgets. This financial autonomy is limited significantly by the requirement the Judiciary's budget stay within parameters determined by the other branches of government in the budget laws. This guarantee is also considerably weaker than the guarantees found in several Latin American constitutions that the courts be allocated a specific percentage of the budget or governmental receipts. ${ }^{57}$ It has not prevented a series of strikes that have virtually paralyzed state judiciaries in many parts of Brazil.

55. Friedlander, "União perde $17.6 \%$ da receita em um ano," Gazeta Mercantil, Oct. 6, 1988 at 7. See also "Constituinte e a Reforma Tributária," 42 Conj. Econ. 7 (No. 8, Aug. 1988).

56. "Constituição e Educação," Gazeta Mercantil, July 25, 1990 at 4.

57. See Rosenn, "The Protection of Judicial Independence in Latin America," 19 U. Miami Inter-Am. L. Rev. 1, 16-17 (1987). 
Long delays in payment of judgments against governmental entities has been a chronic problem in Brazil. To reduce these delays, Article 100 requires that all judgments against federal, state, and municipal governments be paid in chronological order, and that monetarily corrected budgetary provisions be made each year to pay all pending judgments. Unfortunately, this fair and sensible measure has been undercut by Transitory Provision Article 33, which permits governments to pay off unpaid judgments in annual installments over a period of eight years.

A number of new remedies have been created to insure greater judicial protection of constitutional rights. ${ }^{58}$ These new constitutional remedies, particularly the direct action of unconstitutionality, substantially expand the powers of the courts to control governmental actions.

Under the new Constitution, the Supreme Federal Tribunal has become primarily a constitutional court. ${ }^{59}$ The old intermediate federal appeals court, the Federal Tribunal of Recourses, has been replaced by a Superior Tribunal of Justice, which is now the court of last resort for a good deal of the appellate caseload formerly decided by the Supreme Court and the Federal Appellate Tribunal. ${ }^{60}$ Article 98(I) accords constitutional status to small claims courts, a highly successful experiment proposed by Hélio Beltrão, then Minister of Debureaucratization, and authorized by federal statute in $1984 .{ }^{61}$

\section{The military}

The interests of the military, including its right to intervene in matters of national security, continue to be amply protected. ${ }^{62} \mathrm{~A}$

58. See Section VII infra.

59. In addition to resolving constitutional questions, the Supreme Federal Tribunal has original and exclusive jurisdiction to hear: (1) criminal charges against and habeas corpus requests in favor of the President, Vice-President, members of Congress, its own members, and the Procurator General (Art. 102, subparas. I(b) \& (d); (2) criminal and impeachment charges against and habeas corpus in favor of Ministers of State, members of appellate tribunals and the Tribunal of Accounts, and heads of diplomatic missions (Art. 102, subparas. I(c) \& (d); (3) litigation between foreign countries or international organs and the Brazilian government (Art. 102, subpara. I(c); (4) interstate conflicts and conflicts between the federal government and the states (Art. 102, subpara. I(f); (5) international extradition requests (Art. 102, subpara. I(g); and (6) requests for recognition and enforcement of foreign judgments and concessions of letters rogatory (Art. 102, subpara. I(h). The wisdom of conferring original jurisdiction in the last two categories of cases on the highest court, particularly one with an incredibly congested docket, is highly questionable, but this merely continues previous constitutional allocations of jurisdiction. The Supreme Federal Tribunal also has appellate jurisdiction in a small number of cases that may not involve any constitutional issues.

60. The jurisdiction of the Superior Tribunal of Justice is set out in Article 105.

61. See Rosenn, "Civil Procedure in Brazil," $34 \mathrm{Am}$. J. Comp. L. 487, 521-22 (1986).

62. The Army, Navy, and Air Force are declared to be permanent national insti- 
broad amnesty is conceded for all acts motivated solely by political reasons between 1946 and $1988 .{ }^{63}$ Habeas corpus will not lie for infractions of military discipline, ${ }^{64}$ nor does the constitutional guaranty against being arrested without a warrant apply to military offenses. ${ }^{65}$ Sensibly, members of the military have neither the right to strike nor to join unions. ${ }^{66}$

\section{INDIVIDUAL RIGHTS}

Many of the new Constitution's provisions represent significant liberal or progressive advancements, particularly with regard to protection of individual rights and expansion of the rights of the working class. Article 5 protects a large number of individual and collective rights. This enormous article appears to protect virtually every form of known human right. Torture, racism, and others forms of inhuman or degrading treatment are not only prohibited, ${ }^{67}$ but are declared to be nonbailable offenses. ${ }^{68}$ Paradoxically, this provision invites human rights abuses by mandating pretrial detention for persons only accused of such offenses. ${ }^{69}$ Men and women are declared to have equal rights and obligations. ${ }^{70}$ The rights to intimacy and privacy are unqualifiedly guaranteed, ${ }^{71}$ but the significance of such guarantees will have to await judicial interpretation. Since Brazil is the world's largest Catholic country, they are unlikely to be interpreted to support a right to abortion. No one may be arrested without a warrant except in cases of apprehension in flagrante delicto or military transgressions. ${ }^{72}$ No one can enter an-

tutions and military intervention is permitted to protect law and order at the request of any of the constitutional powers. Const. of 1988, art. 142. Military service is obligatory in terms of the law. Id., art. 143. The rights and prerogatives of members of the military are amply protected. Id., art. 42.

63. Id., Transitory Provisions, art. 8.

64. Id., art. $142 \S 2$.

65. Id., art. 5 , subpara. LXI.

66. Id., art. $42 \S 5$.

67. Id., art. 5, subpara. III.

68. Id., art. 5, subparas. XLII \& XLIII.

69. The enormous potential for abuse is readily apparent upon reading Law No. 7.716 of January 5,1989 , which makes racism a criminal offense. The statute simply says in its first article: "Crimes resulting from racial or color bias shall be punished in the form of this law." The remainder of the articles set out punishments ranging from one to five years for denying or impeding access to public or private employment; refusing or impeding access to or refusing service on public transportation or at any commercial establishment, bar, restaurant, hotel, or club open to the public; refusing to allow a student to enroll in a public or private school; and impeding or obstructing, by any means or form, a marriage or family or social living together.

Nowhere does the statute define the mental element necessary for commission of the offense. Presumably, a parent who objected to the color or race of a prospective son or daughter-in-law might be charged with the offense.

70. Const. of 1988 , art. 5 , subpara. I.

71. Id., art. 5, subpara. X.

72. Id., art. 5 , subpara. LXI. 
other's home without consent, except for cases of flagrante delicto, disaster, or rendering aid; otherwise, the police may enter only with a judicial order, and even then only during the day. ${ }^{73}$ Illegally obtained evidence is inadmissible at trial. ${ }^{74}$ Prisoners have a right to be informed of their rights, including their right to remain silent and to have the assistance of family and counsel. ${ }^{75}$ The State must render full legal assistance without charge to those unable to afford it. $^{76}$

In many Latin American constitutions, individual liberties are sharply reduced whenever a state of siege or other form of emergency is declared. Although following this pattern, the new Brazilian Constitution commendably places important constraints upon executive power during times of emergency. The President can declare a state of defense for up to 60 days whenever public order or social peace is threatened and may decree restrictions upon the rights of assembly and the secrecy of the mails, telephones, and telegraphs. ${ }^{77}$ During this period, the executive may imprison persons for up to ten days for crimes against the State, provided the imprisonment is communicated to a competent judge and the prisoner is not maintained incommunicado. The declaration of the state of defense must be submitted to Congress for ratification within 24 hours. ${ }^{78}$ A state of siege may be declared by the President, only if authorized to do so by Congress, and then only in cases of grave commotion or a state of war or its equivalent. ${ }^{79}$ During a state of siege, the executive can require persons to remain in a determined place, detain persons in a building that is not used to house ordinary prisoners, restrict liberty of the press and other communication media, violate the secrecy of correspondence and other forms of communication, suspend freedom of assembly, commit searches and seizures in homes, intervene in public services, and requisition prop-

73. Id., art. 5, subpara. XI.

74. Id., art. 5, subpara. LVI.

75. Id., art. 5, subpara. LXIII. Whether this constitutional right to remain silent will change existing Brazilian law is unclear. Under Article 186 of the Code of Criminal Procedure, Decree Law No. 3.931 of Dec. 11, 1941, the judge has the duty to notify the accused that although he may remain silent, "his silence may be interpreted to prejudice his defense." In addition, Article 198 provides: "Silence of the accused does not imply his confession, but it may constitute an element in convincing the judge."

76. Id., art. 5, subpara. LXXIV. The Constitution also provides for creation of a Public Defender to defend the indigent at all stages of judicial proceedings. Id., Art. 134. See generally, Rogério Tucci \& José Cruz e Tucci, Constituição de 1988 e Processo 19-27 (1989).

77. Const. of 1988, art. $136 \S 1$.

78. Id., art. $136 \S 4$. Within ten days, Congress, by an absolute majority, must decide whether to ratify the state of defense.

79. Id., art. 137. 
erty. ${ }^{80}$ A state of siege for reasons of grave commotion may not be decreed for more than 30 days, and cannot be extended for longer than 30 days at a time. Unfortunately, protection of certain aspects of individual rights is an area in which the gap between the Constitution on paper and the Constitution in practice looms largest. When, on February 5, 1989, police in São Paulo deliberately punished 51 prisoners by cramming them into a tiny unventilated cell, killing 18 prisoners, an editorial in Veja, the Brazilian Newsweek, made the point forcefully:

Today Brazil has one of the most beautiful Constitutions in its history in all that it says with respect to fundamental human rights. . . . Moreover, there is nothing to complain about in relation to our laws in this area. The problem is in the disturbing distance that separates the rights inscribed on paper from their effective exercise, and above all in the guaranty of their exercise in practical life. Such distance has been once again dramatized last week in the massacre of detainees who mutinied in the cells of a São Paulo police station-locked into an unventilated cell as punishment, fortuitously killed by asphyxiation. ${ }^{81}$

Even though Article 5 (XLIX) guarantees "all prisoners respect for physical and moral integrity," torture and maltreatment of common criminals is a fact of life in many Brazilian police stations and jails. ${ }^{82}$

\section{SOCIAL AND ECONOMIC RIGHTS}

Article 6 declares that education, health, labor, leisure, security, social security, protection of maternity and infancy, and assistance of the unprotected are social rights. Article 7 contains 34 subsections that read like a miniature, progressive labor code. ${ }^{83}$ These provisions protect workers from being fired arbitrarily, create unemployment insurance, and continue a successful retirement/severance pay fund for employees called the Fund for Guaranty of Time of Service (FGTS). The minimum wage, which historically has varied from region to region, is unified throughout Brazil and is theoretically fixed at a level sufficient to satisfy the basic necessities of life for each family, with periodic readjustments to preserve its purchasing power. ${ }^{84}$ Salaries cannot be reduced unless permitted by a collective

80. Id., art. 139.

81. Feb. 15, 1989 at 23.

82. Amnesty International, Beyond The Law: Torture and Execution in Urban Brazil (June 1990); Country Reports, supra n. 33 at 487.

83. For more comprehensive treatment of these provisions, see Eduardo Saad, Constituição e Direito do Trabalho 83-214 (1989); Buchanan, "The Future of Brazilian Labor Law under the Federal Constitution of 1988," 10 Comp. Labor L. J. 214 (1989).

84. Const. of 1988, art. 7, subpara. IV. 
bargaining provision. Employees are given a constitutional right to share in the profits as defined by law, ${ }^{85}$ a right which has been theoretically granted but never enforced under Brazilian constitutions since 1946.86 The normal work day is set at eight hours, and the normal work week is set at 44 hours. ${ }^{87}$ Workers are entitled to annual paid vacations with at least a $1 / 3$ bonus over their normal pay. ${ }^{88}$ Women are entitled to at least 120 days of paid maternity leave, while fathers are entitled to a paid paternity leave whose term is to be fixed by law. ${ }^{89}$ Regrettably, little consideration appears to have been given to the question of whether Brazilian firms can afford to pay this increased labor bill, or whether the country is willing and able to shoulder the costs of enforcing these constitutional rights.

Two of the basic principles upon which the economic order is based are declared to be private property and free competition. ${ }^{90} \mathrm{All}$ are assured the free exercise of any economic activity, independent of public authorization, except for cases provided for by law. ${ }^{91} \mathrm{Un}$ fortunately, the insertion of the exceptions clause practically nullifies the general rule, for there is very little economic activity in which one can engage in Brazil without public authorization. Had they a serious commitment to the principle of free competition, the drafters should have guaranteed free exercise of economic activity except for conduct prohibited by the penal law.

The rights of private property appear to be amply protected. Article 5 (XXII) provides in unqualified terms: "The right of property is guaranteed." This guarantee, however, proved of little avail in March 1990, when the Collor Plan froze all bank and savings accounts in excess of $\$ 1200$ for 18 months. ${ }^{92}$ Three days after the Collor Plan was promulgated, the President issued Provisional Measure No. 173, prohibiting the courts from issuing preliminary injunctions or provisional proceedings (ancillary or incidental measures to safeguard the outcome of judicial proceedings) challenging the validity of the Collor Plan. Without reaching the merits, the Supreme Federal Tribunal refused to suspend Provisional Measure No. 173.93

85. Id., art. 7, subpara. XI.

86. See Saad, supra n. 83 at 111-117.

87. Const. of 1988, art. 7, subpara. XIII.

88. Id., art. 7, subpara. XVII.

89. Id., art. 7, subparas. XVIII \& XIX.

90. Id., art. 170, subparas. II \& IV.

91. Id., art. 170 , sole para.

92. Provisional Measure No. 168 of Mar. 15, 1990, confirmed as Law No. 8.024 of Apr. 12, 1990.

93. The 7-2 decision of the Supreme Federal Tribunal is reported in the Gazeta Mercantil, Apr. 6, 1990 at 31 . In a declaratory judgment action brought by the Federal Council of the Brazilian Bar Association and the Democratic Labor Party (PDT), the Supreme Federal Tribunal held that a provisional measure restraining issuance of preliminary injunctions does not contravene the constitutional guarantee of access to the judiciary. Official Gazette (DOU), June 25, 1990. These decisions are 
Since an ordinary action almost always requires longer than 18 months to be resolved, the decision refusing to invalidate the prohibition on issuing preliminary protective measures effectively moots the merits and seriously undercuts the constitutional guarantee of Article V(XXXV), which states "The law shall not exclude from judicial review an injury or threat to a right."

Real property is protected, provided it is performing its social function. ${ }^{94}$ Except for agrarian reform, private property can be expropriated only for necessity, public utility, or social interest, upon payment of just and prior compensation in cash. ${ }^{95}$. Productive rural land can be expropriated for agrarian reform purposes only if it is being used to cultivate narcotics. ${ }^{96}$ Small and medium-sized rural property may not be expropriated unless the owner has other land. ${ }^{97}$ If nonproductive rural property is expropriated, compensation for all useful and necessary improvements must be paid in cash, but the land value may be compensated by bonds, redeemable in up to 20 years, with a maintenance of value clause. ${ }^{98}$ The likely result of these provisions is to hinder any serious efforts at agrarian reform, creating yet another example of the lack of wisdom in attempting to resolve highly controversial social conflicts by constitutional measures, rather than ordinary legislation. ${ }^{99}$

Potentially, the most interesting innovation is the Anglo-American transplant: "No one may be deprived of liberty or property without due process of law."100 It is difficult to predict what meaning will ultimately be placed upon this due process clause by Brazilian courts and jurists. It might well be construed to have a substantive component in light of the gloss placed upon it by U.S. Supreme Court precedents, which are frequently cited by the Brazilian courts when interpreting constitutional provisions transplanted from the United States. ${ }^{101}$

not regarded as binding precedents, however, and lower courts have occasionally been granting preliminary injunctions or relief on the merits against the freeze on bank deposits contained in the Collor Plan.

94. Const. of 1988, arts. 5, subpara. XXIII and 170 , subparas. II \& III. Urban property fulfills its social function when it meets the fundamental exigencies for ordering the city as expressed in its master plan. Id., art. $182 \S 2$.

Rural property fulfills its social function whenever, in accordance with criteria established by statute, it is being rationally and adequately utilized, it is making adequate use of its available natural resources and preserving the environment, its own. ers are complying with labor laws, and its exploitation favors the well-being of its owners and employees. Id., art. 186.

95. Id., art. 5, subpara. XXIV.

96. Id., arts. $185,186 \& 243$.

97. Id., art. 185 , subpara. I.

98. Id., art. 184.

99. Driesen, "Brazil's Transition to Democracy: Agrarian Reform and the New Constitution," 8 Wis. Int l L. J. 51 (1989).

100. Const. of 1988 , art. 5 , subpara. LIV.

101. For a comprehensive treatment of the subject, urging that due process ought 


\section{InNOvations in the PROTECTION OF CONSTItUTIONAL RightS}

The most impressive achievements of the new Constitution are its procedural innovations in the protection of constitutional and legal rights. The framers of the new Constitution determined that existing Brazilian procedural law has been inadequate to protect constitutional rights. The problem is an old one in Brazil. In 1832, the country adopted the Anglo-American writ of habeas corpus, which gradually was pressed into service to protect every certain and incontestable constitutional right. ${ }^{102}$ After habeas corpus was cut back closer to its Anglo-American origins, the Brazilians created a new institution called the writ of security (mandado de segurança) in the 1934 Constitution to protect any liquid and certain right unprotected by habeas corpus. The writ of security combines into a single remedy most of the effective characteristics of the injunction, writ of prohibition, quo warranto, and mandamus. It has been a highly effective, summary remedy for protecting certain kinds of constitutional rights. ${ }^{103}$

\section{The collective writ of security}

The absence of a doctrine of a stare decisis has meant that everyone aggrieved by a particular statute or regulation must bring his or her own writ of security in order to secure relief. ${ }^{104}$ This is expensive and clogs the courts. The Constituent Assembly, therefore, created a collective writ of security that can be brought by any political party represented in Congress, or by any union, business syndicate, or association, legally constituted for more than one year, to defend the rights of its members or associates. ${ }^{105}$ This procedural innovation is another sensible step in the creation of the class action, which began in 1985 as a device to protect the interests of environ-

to have a substantive component, see Carlos Roberto de Siqueira Castro, $O$ Devido Processo Legal e a Razoabilidade das Leis na Nova Constituição do Brasil (1989). See also, Tucci \& Cruz e Tucci, supra n. 76 at 15-18.

102. Eder, "Habeas Corpus Disembodied: The Latin American Experience," in XXth Century Comparative and Conflicts Law 463, 465-69 (Kurt Nadelmann, Arthur von Mehren \& John Hazard eds. 1961).

103. See Karst \& Rosenn, supra n. 4 at 102-24.

104. Brazil does have an analogue to stare decisis called the Sumula, which consists of capsulized authoritative interpretations of legal rules, usually one sentence in length, drawn from the headnotes to decisions of the Supreme Federal Tribunal and several other courts. Judicially created rules are enshrined in the Sumula only after the case law has firmed up, either through en banc uniformity or through several cases taking the same position. Once a rule has become part of the Súmula, further attempts to argue the contrary will be summarily rejected by the tribunal, unless it is prepared to change the Súmula. See Rosenn, supra n. 61 at 513-14 (1986).

105. Const. of 1988, art. 5, subpara. (LXX). For discussions of the procedural implications of the collective writ of security, see Barbi, "Mandado de segurança na Constituição de 1988," 635 Rev. Trib. 19 (1988); Figueiredo, "Breves reflexões sobre o mandado de segurança no novo texto constitucional," 635 Rev. Trib. 24 (1988). 
mental, cultural, and consumer groups. ${ }^{106}$

\section{Habeas data}

The Constituent Assembly also imported from Portugal a new action called habeas data. ${ }^{107}$ This procedure allows anyone to discover all information the government has about him in its data banks and rectify that data if it is incorrect. ${ }^{108}$ Unlike most actions, which require payment of significant amounts as costs, habeas data (as well as habeas corpus) actions are exempted from payment of costs. ${ }^{109}$ A number of habeas data actions have already been instituted in the Brazilian courts.110 In the interest of protecting privacy, however, the drafters of the Constitution appear to have limited standing to bring a habeas data action to a person seeking access to his or her own records and to have excluded heirs or personal representatives. The unfortunate consequence of this omission may be to make habeas data unavailable as a means of finding out the whereabouts of persons who have disappeared.

\section{The direct action of unconstitutionality}

Under the 1969 Constitution, the Supreme Court had the power to determine the unconstitutionality of any law or normative act on its face in a proceeding called a representation. ${ }^{111}$ The Tribunal's decisions in representation actions had erga omnes effects, but only the Procurator General of the Republic had standing to bring such an action. ${ }^{112}$ In the new Constitution, the representation has been renamed the direct action of unconstitutionality, and standing to bring the action has been expanded to include the President of the Republic; the Executive Committees of the Senate, House of Representatives, or state legislatures; a state governor; the Federal Council of the Brazilian Bar Association; any political party represented in Congress; and any syndical confederation or national class en-

106. Law No. 7.347 of July $24,1985$.

107. Const. of 1988, art. 5, subpara. LXXII.

108. It has been argued that habeas data is superfluous because any relief available under habeas data was already available under the writ of security. Cretella Júnior, "O novo e inócuo 'writ' constitucional: o 'habeas data'," 304 Rev. For. 99 (1988).

109. Const. of 1988, art. 5, subpara. LXXVII.

110. On the day after promulgation of the Constitution, the Brazilian Supreme Federal Tribunal received eight suits requesting habeas data. "No primeiro dia, Supremo recebe oito pedidos de 'habeas-data' contra SNI," Gazeta Mercantil, Oct. 7, 1988 at 5.

111. Const. of 1969 , art. 119 , subpara. I(1).

112. M.D.B. v. Procurador-Geral da República, 59 R.T.J. 333 (STF en banc 1971). For the historical development of representation, see Karst \& Rosenn, supra n. 4 at 112-118, 218. 
tity. ${ }^{113}$ This represents a very substantial increase in the ability of the Supreme Federal Tribunal to declare laws and statutes unconstitutional, but it has the unfortunate effect of depriving the Tribunal of the benefit of the opinions of the lower courts, of seeing the actual effect of the statute on litigants, and of being able to duck untimely or too sensitive matters by imposing some barrier to justiciability. Indeed, this power to declare laws unconstitutional in the abstract may prove too broad and eventually embroil the Supreme Federal Tribunal in an undue amount of conflict with the other branches of government.

\section{Unconstitutionality for omission and the mandate of injunction}

Well aware of Brazil's long history of underenforcement of constitutional rights and the non-self-executing nature of the many programmatic provisions, the drafters of Brazil's new Constitution created two new remedies to deal with the problem: (1) an action of unconstitutionality for omission and (2) the mandate of injunction (mandado de injunção). Pursuant to Article 103, the Supreme Federal Tribunal has the power to hear direct actions of unconstitutionality dealing with both governmental commissions and omissions. The declaration of unconstitutionality for omission was designed to cajole or force the other branches to enact regulatory norms needed to effectuate certain constitutional provisions. Whenever it issues a declaration of unconstitutionality "because of lack of measures to make a constitutional rule effective," the Supreme Federal Tribunal is charged with notifying the appropriate Branch to adopt the necessary measures. If the omission is caused by an administrative agency, the Tribunal is to direct that the necessary measures be adopted within thirty days. ${ }^{114}$

The mandate of injunction is a new procedural institution to be granted by the courts whenever lack of a regulatory or implementing rule makes impracticable the exercise of constitutional rights and liberties and the prerogatives inherent in nationality, sovereignty and citizenship. ${ }^{115}$ This intriguing innovation, which bears little resemblance to the Anglo-American injunction, has generated considerable legal confusion, ${ }^{116}$ for it is unclear for which constitutional rights it will lie. There is an inherent contradiction in giving the courts the responsibility for enforcing rights that need regula-

113. Const. of 1988, arts. 102(a) \& 103. Brazil's action of unconstitutionality is still narrower than Colombia's popular action, which permits any citizen (defined broadly to include corporations) to challenge the constitutionality of any statute directly before the Supreme Court. Colombia Const. of 1886, art. 214(2), as amended.

114. Const. of 1988, art. $103 \S 2$.

115. Id., art. 5, subpara. LXXI.

116. See generally, Ulderico Pires dos Santos, Mandado de Injunçao-Estudos e Consideraçōes (1988); Irineu Strenger, Mandado de Injunção (1988). 
tory norms from one of the other branches. Congress has not yet regulated this new remedy, but a recent decision of the Supreme Federal Tribunal has held that the mandate of injunction is self-executing. ${ }^{117}$ In the absence of regulatory legislation, the courts have been utilizing the procedure for the writ of security (mandado de segurança $)^{118}$. This means that a summary procedure with a docket preference, and a decision that has only inter partes effects. ${ }^{119} \mathrm{Nev}-$ ertheless, the conceptual and practical difficulties for courts in implementing constitutional rights that require regulatory legislation in the absence of such legislation has resulted in great judicial reluctance to grant mandates of injunction. ${ }^{120}$ Thus far, the mandate of injunction has not worked. Any successful petitions involve violations of individual rights, which, by the terms of the Constitution, have immediate application. ${ }^{121}$

\section{The popular action}

Brazil's 1934 Constitution established a "popular action" conferring standing upon any citizen to bring an action to nullify or annul any act that injured the public patrimony. ${ }^{122}$ Ultimately, this constitutional action was regulated by a special statute, which defined the kind of injuries that could be redressed by the popular action fairly narrowly and tended to discourage such actions by requiring the plaintiff to bear the costs, at least initially; to have to pay the defendant's attorney's fees if plaintiff failed to prevail; and, if the action were deemed rashly brought, to pay ten times the normal costs. ${ }^{123}$ The new Constitution has expanded the popular action not

117. Decision of Nov. 23, 1989, in Process No. 103-3/DF, reported in Gazeta Mercantil, Nov. 24, 1989 at 29. See also Costa, "Supremo esclarece o mandado de injunção," O Estado de São Paulo, Mar. 11, 1990 at 34.

118. The 1934 Brazilian Constitution created a new procedural institution called the writ of security to protect any liquid and certain right unprotected by habeas corpus. The writ of security combines into a single remedy most of the effective characteristics of the common law injunction, writ of prohibition, quo warranto, and mandamus. It has been a highly effective, summary remedy for protecting certain kinds of constitutional rights. See Karst \& Rosenn, supra n. 4 at 102-124.

119. Many mandate of injunctions cases are decided exclusively by the Supreme Federal Tribunal, which has original jurisdiction in all requests for issuance of a mandate of injunction involving claims that the legislation or rule necessary to implement a constitutional right should have been issued by some agency of the Federal Government. Const. of 1988, art. 105, subpara. I(h).

120. The reluctance of Brazilian courts to grant the mandate of injunction is shown in cases like Costa Filho v. Tribunal Superior Eleitoral, Mandado de Injunção No. 16, 127 R.T.J. 1 (STF en banc 1988); Capanga v. Juiz Eleitoral, Mandado de Injunção No. 5, 128 R.T.J. 1 (STF en banc 1988); Silva Sobrinho v. General Comandate, Mandado de Injunção No. 12, 4 Rev. Sup. Trib. Just. 1393 (Superior Trib. Just. 1989).

121. Id., art. 5, subpara. LXXVII $\S 1$.

122. Const. of 1934, art. 113 (38). See generally, José Afonso da Silva, Ação Popular Constitucional: Doutrina e Processo (1968).

123. Law No. 4.717 of June 29,1965 , arts. $10 \& 13$. 
only to include acts that tend to injure the public patrimony, but also to include acts that injure administrative morality, the environment, and historic and cultural patrimony. ${ }^{124}$ Moreover, the plaintiff, unless he sues in bad faith, is exempted from costs and from having to pay the other side's attorney's fees in the event he loses the case. ${ }^{125}$

\section{Measures of Dubious and Very Dubious Wisdom}

A substantial number of provisions make little or no economic sense and, if enforced, are likely to handicap the development and modernization of Brazil. These measures include certain provisions that hardly belong in a constitution, such as a usury limit or specific regulations of labor and foreign investment.

\section{The crime of usury}

The Brazilian Constitution defines the crime of usury as charging a real rate of interest in excess of 12 percent a year. ${ }^{126}$ Since 1933, Brazil has had a usury law prohibiting the charging of a nominal rate of interest in excess of 12 percent a year. ${ }^{127}$ As one would expect in a country with chronic severe inflation, ${ }^{128}$ Brazil's usury statute has been turned into a dead letter by the courts. ${ }^{129}$ Placing a usury provision in the Brazilian Constitution is not only quixotic, but it also threatens the entire Brazilian financial system with imminent collapse. ${ }^{130}$ Just after the Constitution was promulgated, the Central Bank issued a circular formally adopting the position that the constitutional usury provision was not self-executing and required a complementary law to be implemented. The circular was

124. Const. of 1988, art. 5, subpara. LXXIII.

125. Id.

126. Id., art. 192, subpara. VIII $\S 3$.

127. Decree $\mathrm{N}^{\bullet} 22.626$ of Apr. 7, 1933. Law $\mathrm{N}^{\bullet} 1.521$ of Dec. 26, 1951, art. 4, provides criminal penalties for usury.

128. The official inflation rate for 1988 was 933 percent and 1759 percent for 1989 . Using 1985 as a base year and setting it equal to 100 , the consumer price index for Brazil was up to 304,668 by the end of 1989 . International Monetary Fund, 43 International Financial Statistics 136-137 (Sept. 1990). This means that in 1989, it cost more than three thousand times as much to purchase the same market basket of goods as in 1985.

129. Julian Chacel, Mário Henrique Simonsen \& Arnold Wald, Correção Monetária 19 (1970).

130. In most countries, a usury ceiling of 12 percent in real terms would pose no serious threat to legitimate lenders. Brazil is different. The same week that the usury limitation was approved by Congress, the federal government had to pay 13 per cent annual interest in "real" terms on Readjustable Treasury Bonds. Bittencourt, "Com incredulidade, as instituições lamentam a decisão da Assembléia," Gazeta Mercantil, May 12, 1988 at 6; "Juros tabelados: uma decisão insólita da Constituinte," Gazeta Mercantil, May 13, 14, \& 16, 1988 at 4. A basic problem is that the "real" rate of interest is exceedingly difficult to ascertain in Brazil, in part because of index manipulation and in part because of wide number of indexes in use. 
based upon Opinion No. SR-70 of October 6, 1988, which was issued by then Consultor General of the Republic, Saulo Ramos. ${ }^{131}$ This provision may still create serious problems for the financial sector if and when Congress enacts implementing legislation.

\section{Labor provisions}

Article 8, subparagraph II, prohibits creation of more than a single union representing any professional or economic category, thereby preventing competition and helping to insure the continued weakness of the Brazilian labor movement. Article 9 contains a broad and apparently unrestricted right of all workers to strike, a measure that Brazil is already ruing and which is likely to be restricted by creative interpretation. ${ }^{132}$

Transitory Article 19 is a particularly pernicious and shortsighted provision, granting tenure to all civil servants with at least five years of public service, regardless of whether they have been validly admitted to public service. One of Brazil's most serious economic and administrative problems is how to reduce the bloated bureaucracies of the federal, state and municipal governments. This constitutional provision is a major obstacle to badly needed administrative and economic reform.

\section{Foreign investment}

The Constitution's treatment of foreign investment has been highly controversial and may ultimately retard economic growth. The wisdom of regulating foreign investment in a constitution is exceedingly dubious. Nevertheless, foreign investment was a major subject of debate at the Constituent Assembly, which in this area displayed virtuosity in confusing ordinary legislation with constitutional principle. The first draft included measures to nationalize foreign-owned firms; to limit and to require public disclosure of all sums transferred abroad as royalties, profits, interest, and payments for technology; and to prohibit transfer to foreigners of all lands containing mineral deposits. Although the strident nationalism of

131. Circular No. 1.365 of Oct. 6, 1988. A direct action of unconstitutionality brought by the P.D.T. against the President's Normative Act confirming Ramos' opinion was rejected preliminarily by the Supreme Federal Tribunal-P.D.T. vs. Presidente da República, No. 4-7, Oct. 19, 1988, D.J. Feb. 17, 1989.

132. Const. of 1988 , art. $9 \S 1$. This provision enigmatically states that the law shall define essential services and activities and shall provide about attending to the non-postponable needs of the community. Art. $9 \S 2$ states that abuses are subject to liability under law. In addition, art. 37, subpara. VII states that the right to strike for public employees shall be exercised in the terms and limits defined by law. Such provisions may permit the Congress to restrict the right to strike by enactment of complementary legislation, but Congress has failed to enact legislation restricting strikes in essential services. 
early drafts has been somewhat softened, the Constitution as enacted contains several measures that have generated considerable consternation within the foreign investment community. The most important is the banning of foreign-owned companies from exploring for or extracting minerals. All mineral deposits and hydroelectric sites are declared to be the property of the federal government; mineral exploration and mining is restricted to Brazilian individuals or Brazilians firms with national capital who obtain authorization or a concession from the Federal Government. ${ }^{133}$ The "Brazilian firm with national capital," a juridical concept that has emerged since 1969 in a controversial series of laws and decrees, ${ }^{134}$ is defined constitutionally as "a company whose effective control is permanently under the title, either directly or indirectly, of individuals resident and domiciled in Brazil or entities of domestic public law."135 The Constitution requires the government to give preferential treatment to firms of national capital in the acquisition of goods and services, ${ }^{136}$ a preference that will only make government purchasing more expensive. Moreover, given the huge role the Brazilian public sector plays in many markets, such a preference may well put a number of foreign investors out of business. Foreign-controlled companies presently engaged in mining, mineral exploration, or production of hydroelectric power in Brazil have four years either to give up effective control, or to use the power generated in their industrial processes and to industrialize their mineral output in Brazil. 137 At a time when the other countries of Latin America, not to mention Asia, Europe and North America, are seeking to attract more foreign investment by liberalizing the legal restrictions on foreign capital, and at a time when the Brazilian economy desperately needs new investment and technology, insertion of these nationalistic provisions in the new Constitution is the equivalent of using one's foot for target practice.

Another provision that also takes careful aim at Brazil's own foot is the prohibition on foreign oil companies engaging in oil exploration through future risk contracts with Petrobrás. ${ }^{138}$ These contracts in the past have been quite unprofitable for the foreign oil companies, who have invested some $\$ 1.6$ billion since the program

133. Const. of 1988 , art. $176 \&$ art. $176 \S 1^{\circ}$.

134. The most controversial has been the Informatics Law, Law N. 7.232 of Oct. 29,1984 , reserving large parts of the computer market to firms of Brazilian national capital, defined even more narrowly than in the Constitution. For review of the constitutional issues raised by the concept of Brazilian firm of national capital prior to its validation in the new Constitution, see Gandra da Silva Martins, "Os aspectos legais do investimento estrangeiro na area da informática," 301 Rev. For. 3 (1988).

135. Const. of 1988, art. 171, subpara. II.

136. Id., art. $171 \S 2$.

137. Id., Transitory Provisions, art. 44.

138. Id., art. $177 \S 1$. 
began in 1976. Of the 72 risk contracts in force when this provision was enacted, only 1 had resulted in a viable oil discovery. Given Brazilian dependence on foreign oil, depriving Petrobrás of the access to foreign risk capital and expertise can only be attributed to substitution of nationalistic fervor. Another provision specifically authorizes enactment of legislation temporarily conceding fiscal incentives and market reserves to firms of Brazilian national capital. ${ }^{139}$ This is an open invitation to Congress to extend the market reserve principle of Brazil's highly controversial Informatics Law to other markets.

Rounding out these nationalist provisions is one that quixotically bans all firms and foreign capital from direct or indirect participation in health assistance unless specifically excepted by law. ${ }^{140}$ This is simply a protectionist measure likely to hurt health care delivery.

The combined effect of these nationalistic provisions is difficult to calculate, but it seems fair to state that they at least have contributed to a striking amount of disinvestment. Statistics indicate that in 1986, when many nationalistic proposals were being debated, levels of foreign investment dropped sharply, and capital repatriation and dividend remittance levels increased sharply. Foreign investment levels recovered slightly in 1987, but 1988 and 1989 have witnessed a substantial departure of foreign investment from Brazil. ${ }^{141}$

\section{CONCLUSION}

The new Brazilian Constitution is very much a mixed bag. It has serious problems of both form and substance that make it difficult to live with. Some of these problems are likely to be worked out by judicial interpretation and constitutional amendment or revision, but the Constitution, in its present form, appears destined for a short duration. Indeed, the Constituent Assembly's open invitation to the next Congress to revise it totally in five years is foolhardy and dangerous to the institutional stability of the country.

Brazil's new Constitution is also not likely to endure because it does too little to come to grips with the major economic and social

139. Id., art. $171 \S 1$.

140. Id., art. $199 \S 3$.

141. New direct foreign investment in Brazil fell from a high of U.S. \$1.9 billion in 1981 to only $\$ 432.9$ million in 1986 . Capital repatriation, which had averaged only $\$ 176.4$ million a year in the $1978-85$ period, soared to $\$ 636.7$ million in 1986 . Profit remittances, which had averaged only $\$ 573.5$ million annually between 1979 and 1984 , climbed to a record $\$ 1.278$ billion in 1986 . The rate of outflow appears to have slowed in 1987, but the outflow exceeded the inflow by nearly $\$ 1.2$ billion in 1988 and $\$ 1.7$ billion in the first half of 1989 alone. Data from Central Bank and Gazeta Mercantil, Sept. 1, 1989 at 26. 
problems presently confronting Brazil. Brazil has to control its galloping inflation rate, and that this will entail sharply reducing the huge federal budgetary deficit. This requires dismantling the bloated cartorial state, eliminating superfluous employees and administrative organs. It also means selling off or liquidating inefficient and unproductive state enterprises whose deficits are drains on the Treasury, and improving tax collection procedures. Most importantly, it means increasing the level of productive investment and the productivity of Brazilian labor.

The Collor regime is making a valiant effort to deal seriously with these major problems by slashing public employment, raising taxes, eliminating subsidies, destroying cartels, liberating importation, and introducing a free market economy. Unfortunately, a number of constitutional provisions pose serious obstacles to implementing these important reforms. Without an economic system that delivers more prosperity to the average Brazilian than is being currently delivered, the life of any constitution is likely to be short.

Thus far, the Executive and the Congress have shown they are in no great hurry to implement substantial parts of the Constitution. Congress itself has failed to pass much of the complementary and implementing legislation called for by the 1988 Constitution, ignoring the time periods for enacting such legislation set by the Constitution itself. The most enduring contributions to constitutionalism likely to result from Brazil's recent adventure in legislative constitution-drafting are its articulation of new and important constitutional rights and its creation of new procedural devices for implementing these rights. Hopefully, the 1993 revision will result in retention of the Constitution's good features, which are plentiful, and the jettisoning of its bad features, which are unfortunately also plentiful. 